\title{
PEREMPUAN BERCADAR: ANTARA BUDAYA DAN SYARI'AH
}

\author{
Abdul Aziz \\ Fakultas Syari'ah, IAI Ibrahimy Genteng Banyuwangi \\ Email:aziz@iaiibrahimy.ac.id
}

\begin{abstract}
During this time the veil characterizes a devout Muslim. But in addition to being a devout Muslim character, there is often a perception that the veil is the identity of radicalized women, one of the reasons that they rarely socialize with other than their group, and usually the allegedly terrorist families wearing the veil. This is part of the reason for the emergence of circular guidance to the veil users to remove the veil by the campus UIN Sunan Kalijogo Jogjakarta which then raises the public opinions those who agree and disagree with this new circular and finally the circular is revoked. In this case, a simple problem arises, is the ban on using this veil appropriate to apply? In the context of Islam and nationalism of Indonesia. Certainly not, because linking the veil with radicalism means linking Islam with radicalism, but it is not. In addition, radicalism can arise from anyone, regardless of whether to wear a veil or not. If it is proven to be affiliated with a radical movement, then all that needs to be done is to fend it out of the movement, without having to tell him to take off the usual veil.
\end{abstract}

\section{Keyword: Women, Veil, Radicalism}

\begin{abstract}
Abstrak
Selama waktu ini cadar menggambarkan seorang Muslim yang taat. Tetapi selain menjadi karakter Muslim yang taat, sering ada persepsi bahwa jilbab adalah identitas perempuan radikal, salah satu alasan bahwa mereka jarang bersosialisasi dengan selain kelompok mereka, dan biasanya keluarga teroris yang diduga mengenakan jilbab. Ini adalah bagian dari alasan munculnya panduan sirkular kepada para pengguna jilbab untuk menghapus jilbab oleh kampus UIN Sunan Kalijogo Jogjakarta yang kemudian memunculkan opini publik mereka yang setuju dan tidak setuju dengan edaran baru ini dan akhirnya surat edaran tersebut dicabut. Dalam hal ini, masalah sederhana muncul, adalah larangan menggunakan cadar ini sesuai untuk diterapkan? Dalam konteks Islam dan nasionalisme Indonesia. Tentu saja tidak, karena menghubungkan tabir dengan radikalisme berarti menghubungkan Islam dengan radikalisme, tetapi itu tidak. Selain itu, radikalisme bisa muncul dari siapa pun, terlepas dari apakah akan mengenakan cadar atau tidak. Jika terbukti berafiliasi dengan gerakan radikal, maka semua yang perlu dilakukan adalah menangkisnya keluar dari gerakan, tanpa harus menyuruhnya melepaskan cadar yang biasa.
\end{abstract}

\section{Kata Kunci: Perempuan, Kerudung, Radikalisme}




\section{A. Pendahuluan}

Perempuan memang selalu menarik untuk terus diperbincangkan. Terlalu banyak hal yang harus diselesaikan kaitannya dengan manusia yang telah dinobatkan Allah sebagai hiasan dunia ini sebagaimana termaktub dalam ayat berikut.

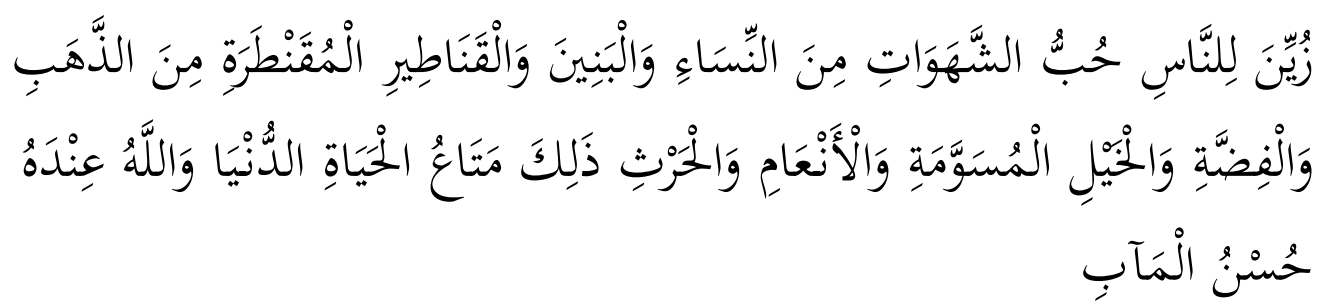

Artinya:"Dijadikan indah pada (pandangan) manusia kecintaan kepada apaapa yang diingini, yaitu wanita, anak, harta yang banyak dari jenis emas, perak, kuda pilihan, binatang-binatang ternak dan sawah ladang. Itulah kesenangan hidup di dunia, dan di sisi Allah tempat kembali yang baik” (QS. Ali Imran 14).

Hal ini juga dipertegas oleh Nabi Muhammad SAW. dengan sabdanya,

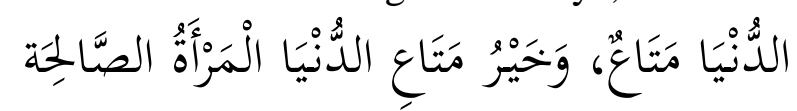

Artinya:" "Dunia adalah kesenangan. Dan paling baiknya kesangan dunia adalah Perempuan" (Muslim: 2. 1090)

Melihat perempuan dalam bentang kesejarahan, maka akan melihat konstruk budaya yang membuat perempuan tertekan. Perbudakan, pemerkosaan, pembunuhan seakan-akan melekat pada diri mereka, dan hal ini hampir terjadi di semua peradaban, seperti Cina, Persia, Romawi, dan Arab (Quraisy; 296). Namun dengan terbukanya kran kebebasan, makanya lalu mereka terlahir secara bebas, atau mungkin bisa dilihat tanpa kontrol. Hak-hak yang dulu tidak mereka dapat sekarang sudah bisa mereka nikmati. Dahulu mereka sebagai penghuni rumah saja, sekarang sudah bebas kemana saja.

Termasuk sebagai tanda kebebasan adalah pakaian. Melihat cara mereka berpakaian maka kita bisa melihat dari tiga zona, yakni: Barat, Arab, dan Indonesia atau Islam Asia tenggara. Di barat mereka menggunakan baju sebebasbebasnya. Hampir tidak ada yang mau ditutupi kecuali hanya kemaluannya saja. Itupun ada yang menggunakan kebebasan berekspresi sebagai dalil untuk tidak menggunakan baju sehelaipun di tempat umum. Sedangkan di kawasan arab, semisal di Arab Saudi berbanding terbalik. Kaum wanitanya menggunaka pakaian 
yang hampir menutupi seluruh tubuhnya, hanya tersisa kedua matanya, itupun kadang ada yang menutupi kedua matanya dengan kain yang terawang, yang cukup sebagai tempat bagi mereka untuk melihat dunia. Untuk di Indonesia bisa disebut sebagai jalan tengah bagi kedua gaya busana di atas. Tidak tertutup semua, seperti di Arab, tapi tidak terbuka seperti di Barat.

Namun seiring berjalannya waktu, gaya busana perempuan indonesia condong ada perubahan. Dengan arus globalisasi yang tumbuh pesat sehingga pada akhirnya pengaruh dari luar masuk. Misalnya, gaya busana barat yang sudah mulai digandrungi, pakaian terbuka sudah mulai disenangi. Sehingga muncullah istilah pakaian you can see. Yang seharusnya tertutup akhirnya terbuka, yang seharusnya tidak layak dipertontonkan sekarang sudah menjadi hiburan mata para laki-laki. Di waktu yang bersamaan pengaruh arab juga semakin besar. Berjubah, jenggot, cadar merupakan salah satu ciri khasnya. Hal-hal tersebut bagi mereka adalah untuk menjalankan syari'at Islam sebagaimana yang dipraktekkan oleh Nabi Muhammad. Meniru atau melakukan segala sesuatu yang telah dilakukan oleh Nabi.

Di antara tiga hal tersebut, permasalahan cadar menjadi perbincangan di tingkat nasional. Penyebabnya muncul dari surat edaran yang dikeluarkan oleh Rektor UIN Sunan Kalijogo. Dalam surat edaran dengan nomor B1031/Un.02/R/AK.00.3/02/2018 tentang pendataan dan pembinaan yang ditadatangani langsung oleh Rektor UIN Suka Yudian Wahyudi, disebutkan bahwa pihak kampus akan memberikan bimbingan konseling kepada mahasiswa yang menggunakan cadar, yang tercatat jumlahnya sebanyak 41 orang. Bimbingan tersebut akan dilaksanakan selama 7 kali. Jika setelah proses bimbingan 7 kali tersebut mahasiswi yang bersangkutan masih menggunakan cadar maka akan dikeluarkan dari kampus (Jogja.Tribunnews.com: 7-3-18).

Ada beberapa alasan dari keluarnya surat edaran tersebut, di antaranya dikhawatirkan yang bersangkutan mengikuti aliran radikal hingga hal negatif yang lainnya. Terlebih sebelumnya ditemukan beberapa bendera HTI yang oleh pemerintah dianggap sebagai organisasi terlarang. Kehawatiran ini muncul karena mahasiswi yang menggunakan cadar cenderung eksklusif. Mereka tidak bersosialisasi dengan mahasiswa lainnya layaknya biasanya. Hal ini seperti ini 
bukan hanya terjadi di UIN Suka, melainkan ada stigma dari masyarakat bahwa pengguna cadar sebagai kelompok ekstrim, eksklusif, dan keras (Amalia. 1). Stigma ini muncul salah satunya karena istri pelaku terorisme banyak yang menggunakan cadar (Ratri. 2011:29) . Selain itu alasan perjokian juga menjadi salah satu sebabnya. Dihawatirkan ketika pelaksanaan ujian bukan orang yang seharusnya ikut, dikarenakan wajah tertutup penuh, sehingga sulit untuk dikenali.

Surat edaran tentang cadar ini langsung memunculkan respon atau tanggapan dari beberapa pihak, seperti Komnas HAM, Ketum MUI, pimpinan DPR dan lain sebagainya. Bagi komnas HAM ini merupakan ancaman bagi kebebasan untuk berekspresi. Sedangkan bagi yang lainnya, dalam Islam ini tidak dilarang, bahkan para ulama banyak juga yang mewajibkan penggunaan cadar bagi kaum perempuan. Lantas kenapa harus dilarang?. Tentu ini merupakan beberapa persoalan yang harus diselesaikan. Misalnya tentang hubungan cadar dengan radikalisme. Apa benar bahwa orang yang menggunakan cadar dekat dengan Radikalisme?. Bukankah mereka menggunakan cadar karena merasa bahwa Islam mewajibkan pemeluknya untuk menggunakannya?, berarti kalau demikian lalu Islam dekat dengan radikalisme.

Berdasarkan pada beberapa masalah di atas, tulisan ini akan membahas cadar dalam ketentuan Syari'at Islam. Apakah cadar merupakan penerapan dari syari'at islam?, atau hanya merupakan budaya orang arab sebagaimana jubah yang merupakan tradisi mereka, sedangkan muslim Indonesia menggunakan sarung. Dan untuk membahas persoalan ini akan diawali dengan pembahasan batasan aurat, karena pembahasan aurat inilah yang menentukan hukum penggunaan cadar.

\section{B. Landasan Teori}

1. Perdebatan tentang aurat perempuan

“Ajining Rogo ono neng busono”, itulah pepatah jawa yang artinya penampilan seseorang tergantung busananya. Busana ini merupakan lambang nilai dari setiap manusia. Karakter kemanusiaan yang memiliki keistimewaan yang luar biasa dibandingkan dengan makhluk lain akan tumbuh dengan adanya pakaian ini. Pakaian sungguh sangat menentukan martabat dari 
seseorang. Martabat sebagai manusia itu akan hilang ketika pakaian tidak melekat pada diri seseorang. Sebagai bukti ketika ada orang tanpa busana mondar mandir di pasar, maka secara otomatis orang-orang akan mengecapnya sebagai orang gila. Inilah hubungannya pakaian dengan sesuatu yang abstrak. Sedangkan fungsi utamanya adalah menutupi tubuh sebagaimana telah disebutkan dalam ayat berikut.

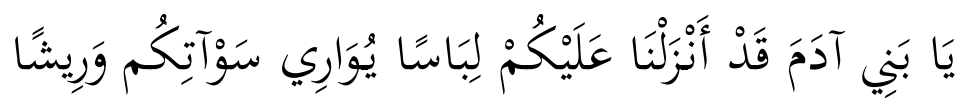

Artinya: "Wahai anak cucu Adam, sungguh kami telah menurunkan untuk kamu pakaian yang dapat menutupi arat-auratmu dan sebagai perhiasan” (QS. Al-A'raf: 26)

Dengan baju inilah muncul adanya perbedaan antara manusia dengan hewan, yang merupakan sesama merupakan makhluk Allah. Dan memang manusia dalam ilmu manthiq didefinisikan sebagai hewan yang berakal. Jadi titik perbedaannya adalah akal. Dengan akal ini lalu manusia berpikir untuk menggunakan pakaian sebagai hiasan dari tubuhnya. Dalam Islam sudah diatur secara ditail tentang pakaian. Dan dengan melihat fungsi pakaian sebagai penutup tubuh, Islam memiliki konsep aurat. Aurat tersebut yang wajib ditutupi dengan pakaian dan menjadi batasan utama dalam berpakaian. Semua ulama sepakat bahwa aurat wajib ditutupi. Bahkan hal ini sudah menjadi kesepakatan di kalangan Ulama. Tidak ada satupun ulama yang berpendapat berbeda tentang ini (Ibn, 2007: 109). Yang menjadi titik perdebatan adalah tentang batasan aurat. Dan ini berbeda-beda tergantung kondisinya.

a. Aurat di dalam shalat

Bagi laki-laki aurat di dalam shalat adalah antara pusar dan lutut. Sedangkan bagi kaum perempuan auratnya seluruh tubuh kecuali telapak tangan dan wajah (Afifuddin. 2014:41).

b. Aurat di luar shalat

1) Aurat laki-laki

Hampir semua ulama sepakat bahwa aurat laki-laki adalah antara pusar dan lutut. Sehingga laki-laki wajib menggunakan pakaian yang bisa menutup hal tersebut. Dan bagi orang lain haram hukumnya melihat 
auratnya ketika terbuka. Namun menurut Imam Malik paha laki-laki tidak termasuk aurat. Maka oleh karena ini, dengan mengikut pendapat ini maka boleh bagi kaum pria menggunakan celana pendek di tempat umum, sebab paha bukan termasuk aurat.

2) Aurat perempuan

Aurat perempuan kalau hubungannya dengan sesama perempuan adalah sama dengan aurat laki-laki, yaitu antara pusar dan lutut. Sedangkan aurat perempuan hubungannya dengan laki-laki yang bukan mahram ada dua pendapat. Pendapat pertama menyebutkan seluruh badan tanpa terkecuali, hal ini merupakan pendapat Syafi'iyyah dan Hanabilah. Sementara pendapat kedua menyebutkan bahwa aurat adalah seluruh badan kecuali telapak tangan dan wajah. Dan pendapat ini dikemukakan oleh Hanafiyah dan Malikiyyah.

2. Analisis dalil tentang aurat

Baik yang menyebutkan bahwa aurat perempuan seluruh badan dan yang mengecualikan wajah serta telapak tangan sama-sama memiliki argumen, baik secara aqli maupun naqli. Di antara dalil-dalil yang dijadikan dasar tentang batasan aurat ini oleh kalangan Syafi'iyyah dan Malikiyah adalah ayat berikut:

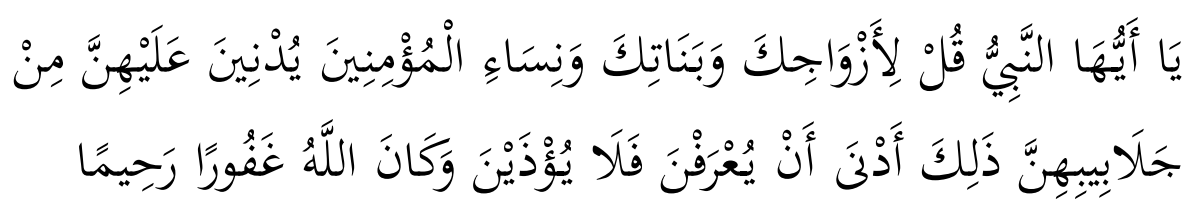

Artinya: "Hai Nabi. Katakanlah kepada isteri-isterimu, anak-anak perempuanmu, dan isteri-isteri orang mukmin: hendaklah mereka mengulurkan jilbabnya ke seluruh tubuh mereka. Yang demikian itu supaya mereka lebih mudah dikenal, karena mereka tidak diganggu. Dan Allah adalah maha penyayang dan pengampun" (QS. AlAhzab: 59)

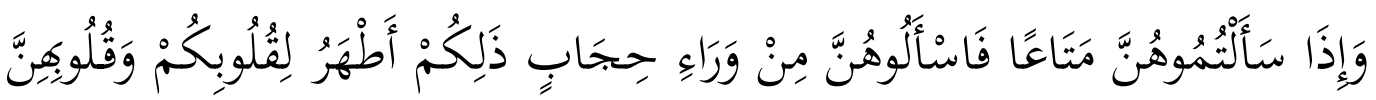

Artinya: “Apabila kamu meminta sesuatu kepada mereka (isteri-isteri Nabi), maka mintalah dari belakang tabir. Cara demikian itu lebih suci bagi hatimu dan hati mereka" (QS. Al-Ahzab: 53)

Dari dua ayat ini dapat dipahami bahwa seorang perempuan harus menutup seluruh tubuhnya. Hal ini sebagaimana tertulis pada ayat yang pertama. Berarti dalam hal ini perempuan sebagai subyek. Sedangkan pada 
ayat kedua, perempuan sebagai obyek, sehingga dijelaskan bahwa kalau ada laki-laki hendak berbicara dengan perempuan maka harus dari balik pembatas. Di samping kedua ayat tersebut, kalangan kelompok ini juga mendasarkan pada beberapa hadits berikut:

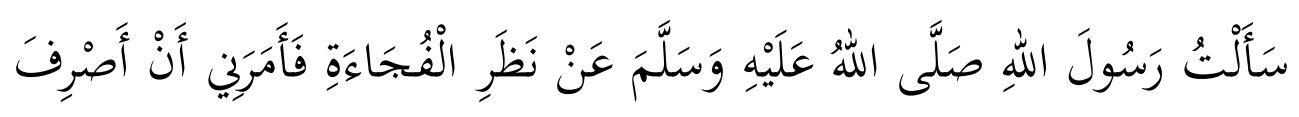

$$
\text { بَصَرِي }
$$

Artinya: "Aku bertanya pada Rasulullah tentang pandangan yang spontanitas (tanpa sengaja), kemudian beliau memerintahkan aku untuk memalingkan pandangan" (Muslim: 3.1699)

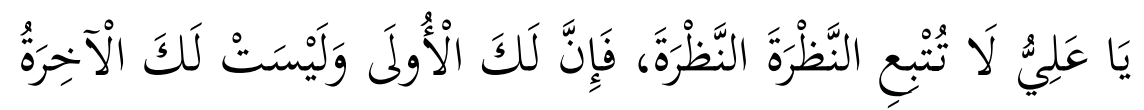

Artinya: "Wahai Ali pandangan yang tidak sengaja jangan diikutkan denganpandangan yang lain, karena yang pertama (bonus) bagimu, sementara yang kedua bukan" (Dawud: 2. 246)

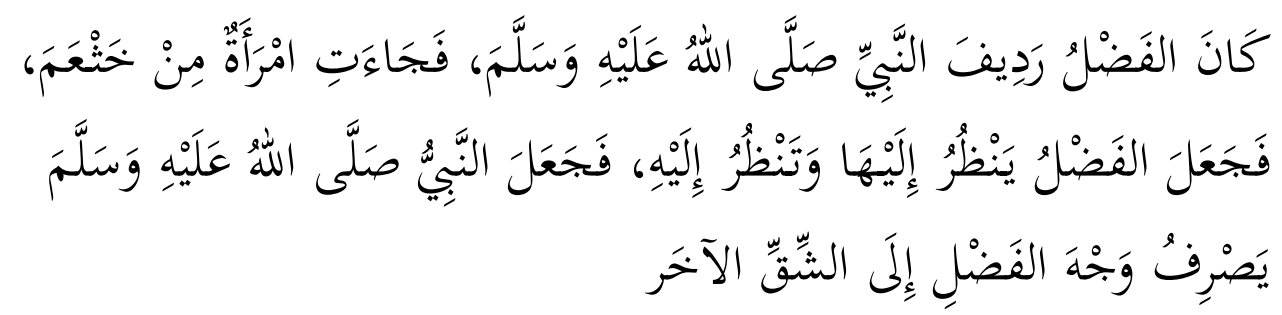

Artinya: “ kemudian datang seorang perempuan dari Khast'am. Lalu Fadhl melihat perempuan tersebut, dan dia juga melihat fadhal. Nabi pun lalu memalingkan wajah fadhal ke sisi (arah) yang lain" (Bukhari: III. 18)

Ketiga hadits ini memiliki kesamaan, yakni bahwa tidak boleh memandang seorang perempuan. Dengan tidak bolehnya memandang ini, mengindikasikan bahwa perempuan wajib menutup seluruh tubuhnya, termasuk wajahnya, sebab masuk kategori aurat. Tujuan utama dari syari'at ini adalah terhindarnya dari fitnah, berupa gangguan para kaum laki-laki. Selain dalil-dalil yang termaktub dalam Qur'an dan Hadits ini, menurut Syekh Ali As-Sobuny yang termasuk ulama kontemporer yang mendukung kelompok ini, dalam kitab fenomenalnya Rawa'iul Bayan beliau menyebutkan:

Artinya: "Secara logika, ketidakbolehan memandang wanita karena dihawatirkan terjadi fitnah. Dan wajah merupakan penyebab fitnah yang lebih dominan daripada kaki, rambut, dan tangan. Sehingga ketika melihat kaki, rambut, dan lengan haram maka melihat wajah 
lebih haram mengingat wajah sebagai penanda keelokan dan penyebab fitnah" (As-Sobuny: 125)

Itulah dalil-dalil yang dikemukan para ulama yang menyebutkan aurat perempuan adalah seluruh tubuh tanpa terkecuali. Sedangkan Hanafiyyah dan Malikiyyah yang tidak setuju dengan pendapat di atas dengan menyebutkan wajah dan telapak tangan bukan aurat karena mendasarkan pendapatnya pada dalil-dalil berikut:

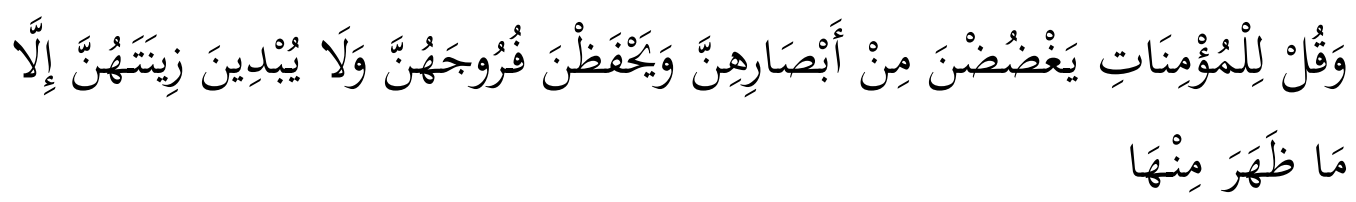

Artinya: "katakanlah pada wanita yang beriman:hendaklah mereka menahan pandangannya, memelihara kemaluannya, serta tidak menampakkan perhiasannya kecuali yang biasa tanpak dari padanya” (QS. AnNur: 31)

Dalam ayat di atas disebutkan pengecualian dengan menggunakan إلَّل مَا ظَهَهَ مِنْهَ Itu artinya tidak semua harus ditutupi. Dan yang dimaksud dengan pengecualian tersebut adalah tangan dan telapak tangan, karena kebutuhan manusia menuntut hal tersebut (Al-Alusi: IX, 335).

Ada hadits nabi yang secara jelas mendukung penafsiran ini,

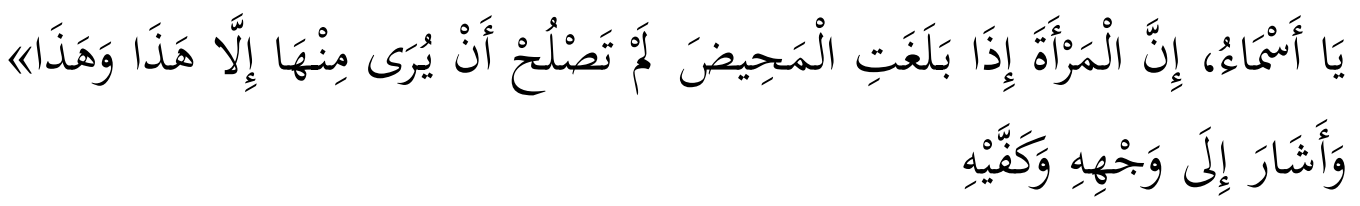

Artinya: “Wahai Asma', Seorang perempuan ketika sudah mencapai usia haidh (baligh) maka dia tidak patut dipandang, kecuali hanya ini dan ini. Rasulullah memberi isyarah dengan wajah dan telapak tangan"

Selain itu dua dalil di atas, kelompok ini berdalil bahwa wajah dan tangan tidak termasuk aurat karena dalam shalat dan ihrom wajah dan telapak tangan terbuka. Seandainya wajah dan telapak tangan termasuk aurat maka niscaya ditutup pula ketika shalat dan ihrom. Terlebih ketika ihrom juga akan terjadi pertemuan bahkan berdesakan dengan lawan jenis di masjidil haram. Dari kedua pendapat ini, manakah yang lebih kuat?. Untuk mengetahuinya pasti harus memperhatikan dalil dari kedua kelompok ini. Misalnya dalil Qur'an 
dari kelompok yang menyebutkan bahwa wajah dan telapak tangan termasuk aurat. Kata kuncinya terletak pada kata يُ2ْنِينَ عَلَيْهنَ مِنْ جَلَابِيبِيهنَ . Menurut AtThabariy sebenarnya ayat ini turun untuk menanggapi fenomena yang ada ketika itu, di mana ketika nabi hijrah ke Madinah bersama sahabat-sahabatnya masih belum memiliki tempat. Sehingga para istri Nabi dan kaum perempuan lainnya keluar pada malah hari untuk memenuhi kebutuhan. Sementara para laki-lakinya duduk di pinggir jalan. Tujuannya untuk apa?. Hal ini terjawab dengan kata ذََلِكَ أَدْنَى أَنْ يُعْرَفْنَ yang artinya biar bisa dibedakan antara budak dan perempuan merdeka (At-Thabary: 20/362). Sehingga dengan demikian pada dasarnya perintah menutup seluruh tubuh bukan menunjukkan wajah dan telapak tangan sebagai aurat melainkan untuk tujuan lain, yakni pembeda antara yang budak dan merdeka.

Sedangkan hadits yang menjadi dalil dari pendapat ini tidak pasti menunjukkan wajah dan telapak tangan sebagai aurat. Karena seandainya menunjukkan hal tersebut maka seharusnya bukan larangan untuk melihat, melainkan larangan untuk membuka wajah dan telapak tangan. Ini mengindikasikan ada hal lain yang dimaksud nabi, yang tidak termaktub dalam hadits tersebut, misalnya larangan melihat ini karena para sahabat tersebut melihatnya dengan penglihatan yang berlebihan. Seandainya tidak dengan penglihatan yang berlebihan niscaya tidak sampai dilarang oleh nabi.

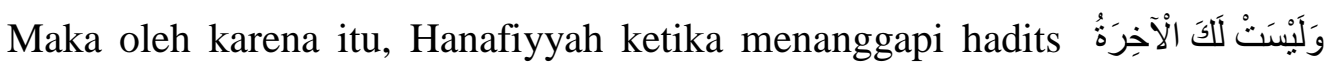
menganggap bahwa pandangan yang dilarang ini karena bersamaan adanya syahwat, bukan mengindikasikan bahwa wajah wajib ditutupi (As-Sarkhosiy, $\mathrm{tt}: 10,152)$.

Adapun dalil yang digunakan oleh kalangn Malikiyyah dan Hanafiyyah lebih bisa diterima. Misalnya dalil Qur'an yang kata kuncinya terletak pada

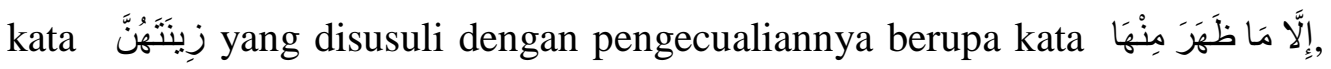
sebenarnya para Ahli Tafsir berdebat tentang hal ini. Ar-Rozi dalam Mafatih Al-Ghaybnya menyebutkan apakah maksud dari hiasan ini adalah yang berupa penciptaan ataukan buatan. Maksud asli adalah anggota badan yang menjadi hiasan dari seorang perempuan. Sedangkan yang buatan seperti bedak, baju, dan perhiasan. Dari kedua pendapat ini ar-Rozi memilih pendapat yang 
pertama dengan dalil bahwa perempuan diperintah untuk menutupi dengan kerudung.

Perdebatan kedua lalu muncul, yaitu kaitannya dengan pengecualiannya. Untuk menjawab hal ini Imam Qaffal menyebutkan bahwa yang dikecualikan adalah wajah dan telapak tangan, karena ini yang berlaku pada masyarakat ketika itu. Menanggapi pernyataan al-Qaffal ini Ar-Rozi menyebutkan bahwa dalam hal wajah memang ditoleransi untuk tidak ditutup karena ada kebutuhan yang menuntutnya dan ini menunjukkan bahwa Islam termasuk agama toleran dan memberikan kemudahan kepada setiap pemeluknya (Ar-Rozi, 23: 364). Dengan kebolehan dibuka, berarti wajah dan telapak tangan bukan aurat. Pendapat ini diperkuat oleh hadits yang diriwayatkan oleh Abu Dawud. Walaupun haditsnya menurut beliau mursal tetapi tetap bisa dijadikan pendukung dari pendapat ini.

Pendapat ini semakin kuat ketika melihat bahwa membuka wajah dan telapak tangan diharuskan ketika shalat dan ihram. Seandainya memang hawatir fitnah terjadi disebabkan terbukanya wajah perempuan di hadapan kaum laki-laki maka niscaya juga harus ditutup ketika ibadah tersebut, terlebih saat ihram, di mana kaum laki-laki dan perempuan berhimpitan saat menjalankan ibadah haji atau umrah. Apakah karena di tempat ini dirasa aman dari fitnah, tentu tidak, melainkan karena wajah dan telapak tangan bukan termasuk aurat.

Walaupun kedua kelompok ini berbeda pendapat tentang batasan aurat, tapi mereka sepakat bahwa dalam hal berpakaian tidak cukup dengan menutup aurat. Kriteria yang juga harus terpenuhi di dalam berpakaian adalah tidak ketat sehingga dapat menampakkan lekuk tubuh. Seperti ditunjukkan oleh hadits berikut:

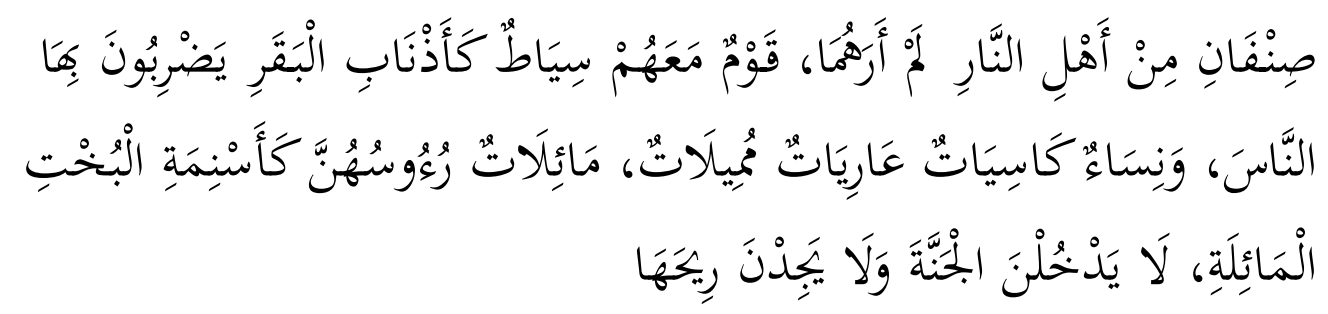

Artinya: "Dua golongan penduduk neraka yang sebelumnya tidak pernah $k u$ temui, kaum yang memiliki pecut seperti seekor sapi yang digunakan untuk mencambuk orang. Perempuan yang berpakaian tapi 
telanjang, menggugah hasrat laki-laki, berjalan lenggak lenggok. Mereka tidak masuk surga dan tidak akan menikmati baunya." (Bukhari, tt: 4:2129)

Hal ini perlu menjadi perhatian utama. Sebab menutup fungsi menutup aurat ini untuk memutus hal-hal yang mengarah kepada fitnah, yaitu berupa perzinahan atau permulaannya (MA. 2014:1-940). Maka bagaimana bisa diputus fitnah tersebut kalau pakaian yang menutupi seperti tidak ada. Yang ada hanyalah kain yang menempel terhadap kulit.

\section{Metode Penelitian}

Penelitian ini termasuk penelitian kepustakaan (library research), yaitu penelitian yang pengumpulan datanya dari materi-materi yang ada dalam kepustakaan, seperti kitab kuning, buku, jurnal dan lain sebagainya (Arikunto. 2005:332). Kepustakaan yang dikaji pastinya yang berkaitan secara langsung atau tidak langsung dengan penelitian ini. Apabila mengikuti pemikiran Cik Hasan Bisri, penelitian ini termasuk penelitian pemikiran Fuqāha (Bisri. 2003:187). Para ahli fiqh yang telah menuangkan pemikirannya tentang cadar. Namun tidak cukup dengan hanya meneliti karya para Fuqaha', melainkan juga harus mengkaji karya Mufassir (ahli tafsir) dan Muhaddits (ahli hadits) sehingga kesimpulan yang didapat sudah melalui kajian yang mendalam. Sedangkan pendekatan yang digunakan dalam penelitian ini adalah kualitatif.

\section{Hasil dan Pembahasan}

1. Pendapat ulama tentang cadar

Cadar dalam bahasa arab diistilahkan sebagai niqab yang memiliki arti kain penutup kepala atau wajah (kbbi.web.id). Dalam penerapannya ini banyak bentuknya, tergantung tradisi masing-masing. Yang paling sederhana hanya berupa secarik kain yang ditempelkan untuk menutup wajah sehingga hanya kelihatan mata, hampir sama dengan masker.

Mengacu pada pendapat yang menyebutkan bahwa wajah dan telapak tangan sebagai aurat maka pasti bagi pengikut pendapat ini mengatakan penggunaan cadar hukumnya wajib. Bahkan Syekh Ali As-Sobuny 
memberikan pembahasan khusus tentang hal ini. Pembahasan yang ada dalam kitab Rawa'iul Bayan berjudul Bid'ahnya Membuka Wajah. Dalam tulisan ini As-Sobuny mengkritik cerdikcendekia yang menyebutkan bahwa tidak perlu pakai cadar. Mereka dianggap sebagai orang yang menganggap diri mereka sebagai ahli dan mau menyaingi para Imam mujtahid terdahulu. Padahal menurutnya, mereka ini hanya para pengikut imam mujtahid, bukan termasuk mujtahid. Di samping as-Sobuny juga menentang pendapat yang mengatakan wajah bukan aurat sebagai dasar tidak perlu menggunakan cadar, karena menurutnya kewajiban hijab tidak ada kaitannya dengan bab aurat, mengingat aurat adalah sesuatu yang wajib ditutup, walaupun kepada mahramnya sendiri. Jadi menurutnya, menggunakan cadar posisinya ada di atas menutup aurat, sehingga walaupun wajah dianggap bukan mahram bukan berarti menafikan kewajiban menggunakan cadar (As-Sobuny. 2. 138)

Sementara itu, bagi ulama yang menyebutkan bahwa wajah bukan aurat maka tidak wajib menggunakan cadar. Bahkan menurut Sayyid Muhammad Thanthawi menggunakan cadar adalah bagian dari budaya, bukan ibadah. Pendapat yang hampir sama dikemukakan oleh Syekh Ali Jumu'ah yang menyebutkan wajah bukan termasuk aurat. Sehingga tidak wajib menggunakan cadar. Sedangkan untuk menjawab dalil-dalil yang dikemukakan kelompok yang mengharuskan penggunaan cadar, beliau menjawab dengan ungkapan berikut (Zaqzuq: 13-16),

"walaupun sebagian ulama mennyebutkan kewajiban menggunakan cadar dengan berpegang pada nash yang masih debatable dalam masalah ini. Padahal Jumhur Ulama sudah memberikan penjelasan bahwa segala sesuatu yang masih bersifat kemungkinan maka tidak boleh istidlal dengan hadits tersebut. Dan ketika bertentangan dali maka berlaku kaidah:Yang asal adalah bebas dari beban taklif"'.

Dengan demikian, maka tidak ada taklif untuk menggunakan cadar karena dalil yang dipakai sebagai dasar kewajibannya masih debatable. Pendapat sedikit keras disampaikan oleh kalangan Malikiyyah. Menurut mereka menggunakan cadar hukumnya makruh apabila bukan merupakan adat kebiasaan di daerah tertentu. Namun apabila di sebuah daerah sudah menjadi kebiasaan menggunakan cadar, maka hukum bercadar adalah mubah (Alaisy: I, 226). Kalangan Malikiyyah ini berani untuk menghukumi makruh dalam 
penggunaan cadar. Bahkan apabila menggunakan cadar saat shalat dianggap sebagai keterlaluan dalam beragama.

Ketika memperhatikan pada kedua pendapat ini, sangat jelas perbedaan landasan dalilnya, dan satu sama lain berpegang tegung pada pendapat masing-masing. Sama dalam satu pendapat pun sepertinya tidak mungkin, karena pendapat yang disampaikan Syekh Ali Juma'ah dan yang lainnya yang tidak mewajibkan menggunakan cadar tidak diterima oleh Syekh Ali AsSobuny. Cara berfikirnya dianggap keliru, sehingga hasilnya pun keliru. Namun kalau kita perhatikan, secara gamblang, apa yang disampaikan oleh Ali As-Sobuny, sulit untuk diterima. Sebab mana mungkin kewajiban menggunakan cadar tidak ada kaitannya dengan kewajiban menutup wajah karena dianggap aurat. Bukankah cadar bagian dari menutut aurat wajah?. Inilah yang agak janggal, sehingga pendapat yang tidak mewajibkan cadar bisa disebut lebih unggul dari segi metode istidlal.

2. Cadar dalam Budaya Islam Indonesia

Secara umum, bangsa Indonesia dikenal sebagai pengikut Syafi'iyyah. tapi tidak dalam semua persoalan. Sebab dalam bab muamalah misalnya lebih condong terhadap pendapat Hanafiyyah atau Malikiyyah, dikarenakan lebih mudah diterapkan sesuai dengan kondisi Indonesia. Untuk masalah pakaian, penggunaan cadar masih sangat jarang dibandingkan dengan penggunaan kerudung atau jilbab. Tidak hanya oleh kalangan biasa, melainkan kalangan keluarga kiai yang dianggap sebagai tokoh agama hanya menggunakan jilbab. Biasanya yang menggunakan cadar hanyalah keturunan Habaib atau orang arab lainnya. Kalau tidak demikian biasanya dilakukan oleh orang-orang yang ada hubungannya dengan arab, seperti pernah belajar di Arab. Ini mengindikasikan bahwa cadar bukanlah tradisi orang Indonesia. Namun melihat fakta yang terjadi, penggunaan cadar semakin meningkat (Indra. 2016:2). Kalau kita tarik dalam kesejarahan, cadar sebenarnya bukanlah budaya Islam, melainkan budaya Arab, sebagaimana jubah bagi kaum lakilaki. Sehingga yang menggunakan cadar bukan hanya orang arab. Karena budaya ini sudah ada sejak sebelum datangnya Islam. Yakni sebagai pembeda antara perempuan merdeka dan budak (Zamakhsyari, tt: 3, 560). 
Ketika cadar bukan budaya arab, apakah lalu boleh pelarangan penggunaan cadar di ruang publik seperti di Kampus atau sekolah? Pertama kita pahami bahwa secara umum bangsa Indonesia mengikuti pendapat yang menyebutkan wajah bukan termasuk aurat. Maka menggunakan cadar bukanlah keharusan. Dengan demikian pada dasarnya tidak apa-apa larangan penggunaan cadar. Terlebih apabila ada indikasi dampak negatif dari penggunaan cadar. Seperti dalam pernikahan di Indonesia pernikahan dianggap sah ketika ada saksi dan wali. Kalau syarat tersebut tidak terpenuhi maka nikahnya tidak dianggap sah. Padahal ada pendapat yang memperbolehkann nikah tanpa saksi atau wali.

Namun pelarangan penggunaan cadar bisa juga kurang tepat atau tidak tepat, apabila dikaitkan dengan terorisme. Sebab dengan demikian akan menimbulkan indikasi bahwa Islam merupakan sarang teroris. Padahal sudah secara jelas bahwa islam datang sebagai rahmat bagi alam. Maka oleh karena itu, kalau memang ada indikasi negatif tentang radikalisme maka tidak perlu disuruh membuka cadarnya, melainkan pembinaan tentang radikalisme. Karena memang tidak ada hubungannya antara cadar dengan radikalisme. Tindakan radikal bisa dilakukan oleh siapapun, baik yang berjilbab, bercadar, atau bahkan oleh yang tidak menggunakan keduanya. Misalnya yang menggunakan cadar jarang bersosialisai, maka mereka perlu dibimbing sehingga mau bersosialisai.

\section{E. Kesimpulan}

Berdasarkan pada pembahasan yang telah dipaparkan, maka dapat diambil beberapa kesimpulan, yaitu:

1. Para masih tidak dalam satu pendapat tentang batasan aurat bagi perempuan. Hanafiyyah dan Malikiyyah menyebutkan wajah dan telapak tangan bukan aurat. Sementara Syafi'iyyah dan Hanabilah menganggapnya sebagai aurat. Dan ketika melihat dari dalil-dalil yang dipaparkan oleh kedua kelompok ini, dalil yang disampaikan Hanafiyyah dan Malikiyyah lebih kuat dengan melihat aspek dalalatul Lafzhinya. 
2. Pada dasarnya, penggunaan cadar sudah ada sebelum diutusnya Nabi Muhammad SAW. sehingga sebenarnya cadar ini sudah tradisi umat sebelumnya. Maka tidak heran kalau sebagian ulama menyebutkan bahwa cadar bukan tradisi Islam melainkan tradisi Yahudi.

3. Sebagai konswensi dari pendapat tentang aurat, maka bagi yang menyebutkan wajah sebagai aurat maka wajib menggunakan cadar. Sedangkan ulama yang tidak menganggapnya sebagai aurat tidak mengharuskan penggunaancadar. Bahkan makruh hukumnya ketika cadar bukan merupakan tradisi pada daerah tertentu.

4. Pelarangan penggunaan cadar dengan alasan radikalisme tidak bisa dibenarkan, karena akan memberikan pemahaman bahwa Islam dekat dengan radikalisme, serta radikalisme bisa dilakukan oleh siapapun, apapun pakaiannya dan agamanya. Lebih tepat ketika perempuan yang menggunakan cadar ketika terindikasi radikalisme diberikan pemahaman yang tepat, tanpa harus melepaskan cadarnya yang dia lakukan sesuai kepercayaanya yang menganggap bahwa menggunakan cadar merupakan sebuah kewajiban, dan hal ini sudah sesuai dengan pendapat para ulama mu'tabarah.

\section{Daftar Pustaka}

Abu Abdillah al-Malikiy, tt, Minahul Jalil Fi Mukhtashar Khalil, Maktabah Syamilah

Abu Dawud, tt, Sunan Abu Dawud, Maktabah Syamilah

Afifuddin Muhajir. 2014. Fathul Qarib al-Mujib, Al-Maktabah Al-As'adiyyah, Situbondo

Al-Alusi, Syihabuddin Mahmud Bin Abdullah Al-Husaini, tt, Ruh al-Ma'aniy Fi Tafsiril Qur'an, Maktabah Syamilah.

Al-Bukhariy, Muhammad Bin Isma'il, tt, Shahih Bukhari, Maktabah Syamilah

Al-Rozy, Abu Abdillah bIn Umar, tt, Mafatih al-Ghayb, Maktabah Syamilah.

Al-Sarkhosy, Muhammad Bin Ahmad Bin Abi Sahl Syamsul Aimmah, tt, alMabsuth, Maktabah Syamilah

Al-Zamakhsyari, Abul Qasim Mahmud, tt, Al-Kasyyaf an Haqaiq Ghawamid alTanzil, Maktabah Syamilah

Arikunto. Suharsimi. 2005. Managemen Penelitian Jakarta. Rineka Cipta

Bisri. Cik Hasan. 2003. Model Penelitian Fiqh: Paradigma Penelitian Fiqh dan Fiqh Penelitian. Jakarta Timur. Prenada Media.

Ibnu Rusyd. 2007. Bidayatul Mujtahid wa nihayatul muqtashid. dar al-fikr, Beirut 
Indra Tanra, Muhammad Nawir, Syarifuddin. 2016. Persepsi Masyarakat Tentang Perempuan Bercadar, Jurnal Equalibrium, Volume: 01. FKIP Unismuh Makassar, Makasar.

Ma'had Aly Salafiyah Syafi'iyyah. 2014. Fikih Progresif: Bunga Rampai Pemikiran Santri Ma'had Aly dalam Buletin Tanwirul Afkar. Situbondo. Ibrahimy Press

Mahmud Hamdi Zaqzuq. 2008. An-Niqab Adatun wa Laisa Ibadatun: Ar-Ra'yu al-Syar'iy Fi al-Niqabi Bi Aqlami Kubbari al-Ulama'. Kairo. Dar alKutub al-Mishriyyah.

Muhammad Ali As-Shobuniy. 2010. Rawa'iul Bayan Tafsiru Ayatil Ahkam Minal Qur'an. Beirut. DKI

Muslim Bin Hujjaj, tt, Shahih Muslim, Maktabah Syamilah

Umi Latifah. 2017. Skripsi, "Perempuan Bercadar dalam Gerakan Pemberdayaan (Study Kasus Komunitas Perempuan Di Yayasan Pendidikan Islam AlAtsari Di Pogung Dalangan, Siduadi, Sleman, Yogyakarta)”, Fakultas Ushuluddin dan Pemikiran Islam, Universitas Islam Negeri Sunan Kalijogo, Yogyakarta. 